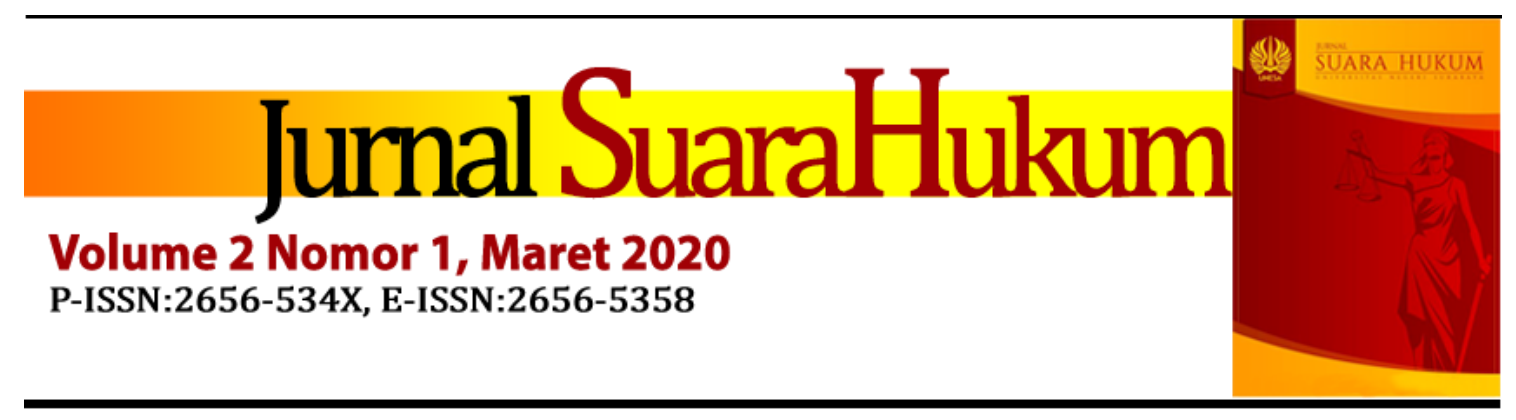

\title{
Peran Aparatur Pemerintah Desa dalam Meningkatkan Partisipasi Politik Penyelenggaraan Pemilu Tahun 2019 Desa Mlagen, Magelang
}

\section{Indira Swasti Gama Bhakti ${ }^{1}$ dan Tri Agus Gunawan²}

${ }^{1}$ Fakultas Ilmu Sosial dan Ilmu Politik, Universitas Tidar, Magelang, Indonesia, indiraswatigb@gmail.com

${ }^{1}$ Fakultas Ilmu Sosial dan Ilmu Politik, Universitas Tidar, Magelang, Indonesia, gunawan5858@gmail.com

\begin{abstract}
Election (Election) is one of the means of democracy in the implementation of popular sovereignty within the Unitary Republic of Indonesia which is based on the Pancasila and the 1945 Constitution. Through elections conducted the people can elect leaders who are expected to be able to bring change towards a better life. Elections are also a means for the people to choose their trusted representatives to carry out various government affairs. Elections must be based on people's awareness to vote, not because of coercion or pressure. The higher the level of people's participation in the election, it means that the higher the level of their political awareness. Villagers who on average are still well educated understand politics only limited to a party of the people which is carried out every five years, and not a few political participation by the community is still influenced by movements from the ruling parties including the village head. The role of the village head is very important to be needed with the situation of rural educated people who are still quite low and most are farmers, this is what was described in Mlagen Village, Bandongan District. The role of the village head is very necessary in order to increase public political participation in the presidential election in 2019. The research method used is a qualitative research method with descriptive analysis techniques. Data collection is done through observation, interviews and documentation. Research data sources are key informants, informants, research sites and documents.
\end{abstract}

Keywords: Role, Village Head, Political Participation, General Election. 


\section{Pendahuluan}

Pemilihan umum (Pemilu) merupakan salah satu sarana demokrasi dalam pengimplementasian kedaulatan rakyat dalam wadah Negara Kesatuan Republik Indonesia yang berdasarkan Pancasila dan Undang-Undang Dasar 1945. Melalui pemilihan yang dilakukan rakyat dapat memilih pemimpin yang diharapkan mampu membawa perubahan kearah kehidupan yang lebih baik. Pemilu juga adalah sebuah sarana bagi rakyat untuk memilih wakil-wakilnya yang terpercaya guna menyelenggarakan berbagai urusan pemerintahan. Urusan pemerintahan tersebut bisa berbentuk membuat kebijakan, mengontrol pelaksanaan kebijakan, ataupun memilih pemimpin pemerintahan. Pemilihan wakil-wakil tersebut bertujuan untuk memilih orang untuk mengisi jabatanjabatan Politik tertentu di dalam sebuah kekuasaan seperti Presiden/Wakil Presiden, DPR Pusat/Daerah, DPD dan Kepala Daerah. Pada umumnya, Pemilu menganut asas langsung, umum, bebas dan rahasia, dengan pelaksanaannya sendiri harus jujur dan adil, disamping itu Pemilu harus didasarkan kepada kesadaran rakyat untuk ikut memilih, jangan karena paksaan atau tekanan. Semakin tinggi tingkat partisipasi rakyat dalam Pemilu, berarti semakin tinggi pula tingkat kesadaran Politik mereka.

Demokrasi merupakan bentuk atau sistem pemerintahan dimana segenap rakyat turut serta dalam pemerintahan dengan perantaraan wakil- wakilnya atau pemerintahan rakyat. ${ }^{1}$ Inti dari demokrasi ialah pemerintah dari rakyat, oleh rakyat dan untuk rakyat. Sistem pemerintahan yang demokratis hingga saat ini masih dianggap sebagai system pemerintahan yang terbaik. Setiap warga negara pada dasarnya tidak ada pembedaan atas hak dan kewajibanya dalam kehidupan sosial bernegara, semuanya sama dihadapan hukum dan pemerintahan. Termasuk dalam hal ini adalah hak berpolitik, hak untuk memberikan pendapat dan hak untuk melakukan koreksi atas pemerintahan. Pergantian kepemimpinan sebagai salah satu keniscayaan dalam sistem

\footnotetext{
${ }^{1}$ H. Nasuka, Partisipasi Rakyat dan Anggota TNI dalam Pemilu, Bandung: Mandar Maju, 2007, Hlm. 12
} 
demokrasi menuntut keterlibatan warga negara didalamya. Adapun miniatur dari pemerintahan negara adalah pemerintahan desa, dimana masyarakatnya masih menjunjung tinggi sifat kekeluargaan dan gotong royong. Sehingga pemerintah mempunyai perhatian khusus terhadap pemerintahan desa terbukti atas disahkanya UU No 6 Tahun 2014 tentang Desa, diharapkan mempunyai paradigma baru bahwa perubahan baik ekonomi, pembangunan, dan kebijakan politik bukan hanya dari kota saja, akan tetapi membangun Indonesia harus mulai dari Desa.

Pemilihan umum tidak dapat terpisahkan oleh politik, karena pemilu merupakan alat kekuasaan untuk mencapai tujuan bersama. Pesta demokrasi yang berlangsung di Indonesia mulai dari pemilihan Presiden dan wakil Presiden, pilkada, dan pemilu legislatif secara langsung merupakan gambaran dari berjalannya sistem demokrasi di negara ini. Meskipun demikian proses demokrasi selama ini belum sepenuhnya menggambarkan masyarakat paham akan arti demokrasi. Masyarakat desa yang rata-rata masih berpendidikan rendah memahami politik hanya sebatas pesta rakyat yang dilakukan setiap lima tahun, dan tidak sedikit partisipasi politik yang dilakukan masyarakat masih dipengaruhi oleh adanya gerakan-gerakan dari pihak-pihak yang berkuasa termasuk kepala desa.

Berdasarkan hal tersebut maka, peran kepala desa sangatlah penting diperlukan dengan keadaan masyarakat pedesaan yang berpendidikan masih cukup rendah dan kebanyakan adalah petani, hal inipun yang digambarkan di Desa Mlagen Kecamatan Bandongan. Kepala desa merupakan birokrat yang mempunyai kekuasaan tertinggi ditingkat desa, dimana kepala desa sangat berperan penting terhadap proses berjalannya pemerintahan desa menuju kesejahteraan masyarakat. Sosok kepala desa merupakan orang yang sangat dihormati di kalangan masyarakat. Selain sebagai pemimpin desa, kepala desa juga merupakan elit lokal yang sangat berpengaruh bagi masyarakat. Besarnya pengaruh kedudukan kepala desa terhadap masyarakat, sering menjadikannya sebagai panutan bagi masyarakat. Berdasarkan uraian pada latar belakang 
masalah dan identifikasi masalah di atas, maka pokok masalah dalam penelitian ini dapat dirumuskan terkait bagaimana peran Kepala Desa dalam meningkatkan partisipasi politik masyarakat pada Pemilhan Umum Presiden tahun 2019 di Desa Mlagen Kecamatan Bandongan Kabupaten Magelang serta apa hambatan Kepala Desa dalam meningkatkan partisipasi politik masyakayat pada Pemilihan Umum Presiden tahun 2019 di Desa Mlagen Kecamatan Bandongan Kabupaten Magelang.

\section{Metode Penelitian}

Penelitian ini menggunakan jenis atau metode penelitian deskriptif kualitatif. Menurut Moleong penelitian deskriptif adalah penelitian yang berupaya mengungkapkan suatu masalah dan keadaan sebagaimana adanya, untuk itu peneliti dibatasi hanya mengungkapkan fakta-fakta dan tidak menggunakan hipotesa. Penelitian deskriptif bertujuan untuk menggambarkan secara tepat sifat-sifat individu dan keadaan sosial yang timbul dalam masyarakat untuk dijadikan sebagai obyek penelitian. ${ }^{2}$ Pada penelitian kualitatif, peneliti memasuki situasi sosial tertentu, melakukan observasi dan wawancara kepada orang-orang yang dipandang tahu tentang situasi sosial tersebut. Penentuan sumber data pada orang yang diwawancarai dilakukan secara purposive, yaitu dipilih dengan pertimbangan dan tujuan tertentu. Informan dalam penelitian ini ialah Kepala Desa Mlagen dan Aparat Pemerintah Desa. Lokasi penelitian berada di Desa Mlagen, Kecamatan Bandongan, Kabupaten Magelang. Adapun teknik Pengumpulan data yang digunakan dalam penelitian ini adalah: a) Observasi; b) Wawancara; c) Dokumentasi. Dalam menganalisia data, peneliti akan berpedoman pada langkah-langkah yang meliputi: a) Pengumpulan data; b) Editing; dan c) Penafsiran data.

\footnotetext{
${ }^{2}$ Moleong Lexi J, Metode Penelitihan Kualitatif. Bandung: PT. Remaja Rosdkarya, 2006, Hlm. 11.
} 


\section{Hasil Penelitian Dan Pembahasan}

3.1. Peran Kepala Desa dalam meningkatkan partisipasi politik masyarakat pada Pemilhan Umum Presiden tahun 2019 di Desa Mlagen Kecamatan Bandongan Kabupaten Magelang

Suprayitno Agus Cahyono selaku Pejabat Sementara Kepala Desa Sidorejo mengungkapkan,

“Peran perangkat dalam hal ini Kepala Desa, dimana saya telah satu periode selama 6 tahun menjabat sebagai Kepala Desa Sidorejo biasanya untuk pemilihan baik itu pemilihan bupati ataupun pilpres, warga desa Sidorejo memang kurang antusias dikarenakan mereka awam politik. Warga desa lebih memilih untuk golput dikarenakan mereka kurang merasakan dampak dari terpilihnya seseorang menjadi presiden bagi kehidupan pribadi mereka. Memang tidak pernah ada kendala (pelaksanaan pemilu) yang berarti selama ini saat saya menjabat sebagai kepala desa atau sering disebut sebagai Lurah. Kalau saya mengartikan lurah itu diwaktu ndalu (malam) kita memberi arah. Selain dapat diartikan sebagai memberi arah atau meminta arah kepada Allah SWT agar desa tetap dalam kondisi atau keadaan yang tentram dan aman (ayem tentrem gemah ripah loh jinawi). Fenomena yang biasa terjadi saat musim pemilu adalah hanya sebagian warga desa yang memilih menurut hati nurani, sisanya atau lebih banyak warga desa yang memilih baik itu presiden maupun anggota legislatif karena adanya serangan fajar dari para paslon. Dan serangan fajar itu yang dirasa mereka paling banyak jumlah dan jenisnya. (hahaha hal biasa yang sering terjadi ya, hal ini disebabkan seperti yang sudah saya sampaikan diawal tadi karena banyak warga kami yang masih sangat awam terhadap pemilu itu tadi) tapi untuk Pemilu tahun ini, sepertinya tidak lagi ada serangan-serangan fajar seperti tahun-tahun yang lalu.

Pada pilpres dan pemilu legistlatif tahun 2019 ini, di desa Sidorejo terdapat 10 TPS yang terdiri dr 6 RW. Adanya peran aparat desa yaitu 
membimbing masyarakat, memberikan pengarahan kepada masyarakat, dan menjalin kerjasama dengan masyarakat. Meskipun, pada akhirnya masyarakat akan menentukan untuk berpartisipasi ketika partisipasi tersebut memberikan keuntungan secara nyata kepada dirinya. Kades juga berperan menjadi pengayom berikut perangkat seperti menjadi bendahara. Perangkat bertugas mengarahkan dan mengikuti alur. Dan tidak ada nama pemilih A5 yang menjadi daftar pemilih di Desa Sidorejo. Petugas TPS sudah ditentukan dari KPU, sedangkan perangkat harus netral. Pengawas partisipatif dr Panwaslu, dari Bawaslu ada petugasnya. Untuk Pansung atau dikenal dengan pengawasan langsung itu oleh Linmas. Linmas adalah ujung tombak dari pengamanan selama proses pemilu berlangsung. Linmas ada di bawah pengawalan Babinsa dan Bhabinkatibmas. Dimana Bhabinkatibmas ini, dibawah binaan dari kepolisian dan Babinsa di bawah binaan Koramil. Satu desa terdapat satu Bhabinkatibmas khusus di kecamatan Bandongan sudah terplot demikian. Sebab di kecamatan lain, satu Bhabinkatibmas bisa menjaga dua sampai tiga desa."

Wawancara berikutnya yang dilakukan oleh Tim Peneliti guna memperoleh informasi setelah pelaksanaan Pemilu Pelaksanaan Pemilu 2019 yaitu terhadap Bapak Adang Prasetyo selaku Sekretaris Desa:

“Setelah Putusan MK dalam hal gugatan MK mengenai Pilpres tidak ada masalah, terutama untuk tim sukses ataupun saksi-saksi dr penggugat 02. Tidak ada selisih suara dan tidak ada penghitungan suara ulang. Jumlah 10 TPS di Desa Sidorejo, terdiri dr 6 dusun yang sebetulnya terdiri dari 9 dusun namun digabung menjadi 6 dusun untuk pelaksanaan Pemilu. Berbeda dengan tahun kemarin, tugas TPS di tahun lalu setelah proses pemilu selesai tugas mereka juga selesai, namun, tahun ini tugas TPS harus buat laporan setelah selesai Pemilu ke KPU bahwa telah melaksanakan proses Pemilu secara luber jurdil. Upaya yang dilakukan oleh aparat desa untuk mengatasi hal yang mungkin 
terjadi setelah penghitungan suara hasil pemilu adalah membentuk panitia pengawas Pemilu tingkat desa yang dibentuk dalam rangka untuk mewujudkan penyelegaraan pemilihan umum yang berintegritas dan berkredibilitas serta penyelenggaraan pemilihan umum yang berasaskan langsung, umum, bebas, rahasia, jujur, adil, dan demokratis. Mengenai serangan fajar atau sering disebut Money Politic memang kerap terjadi di masa-masa pemilu. Namun, hingga proses pelaksanaan Pemilu tahun ini sepertinya tidak ada lagi kegiatan tersebut terjadi di desa kami. Penyebab terjadinya hal tersebut karena memang kami akui sebagai aparat desa, warga kami masih belum memiliki kesadaran berpolitik yang cukup. Penyebab pertama, mungkin dikarenakan figur pemimpin yang diajukan dalam suatu pesta demokrasi kurang berkenan di hati warga desa sebagai pemilih. Penyebab kedua pemilih mulai jenuh dengan proses demokrasi lima tahunan yang tidak membawa perubahan bagi kehidupan rakyat. Penyebab ketiga, pemilihan umum (baik itu Pilkada, Pemilu Legislatif dan Pemilu Presiden) tidak lagi dipandang warga desa sebagai sesuatu yang prioritas atau sangat diperlukan dalam membangun kehidupannya sehari-hari. Serta, faktor penyebab rendahnya partisipasi politik dalam setiap momentum pemilu karena adanya pemahaman bahwa memilih adalah sebuah hak dan bukan merupakan suatu kewajiban."

Wawancara terakhir Tim Peneliti lakukan terhadap Ibu Atiek Budiyarti sebagai warga desa yang berstatus sebagai pendidik di salah satu sekolah dasar di daerah Kabupaten Magelang. Didapati hasil dari wawancara bahwa pada masa Pemilu ini, Ia memiliki anak didik yang menjadi bagian dari tim sukses dan diperbolehkan serta didukung oleh orang tuanya (ayah) untuk terlibat menjadi tim sukses bersama dengannya saat masa kampanye Pemilu 2019, hingga si anak (siswa) tersebut tidak masuk sekolah. Melihat fenomena ini, meskipun terlibatnya warga Negara 
dalam proses Pesta Demokrasi tidak dengan begitu saja dapat diartikan bahwa para tim sukses ini memang betul sadar akan politik. Dapat dilihat, bagaimana kondisi anak SD yang masih duduk di kelas 4 dapat memahami arti politik layaknya manusia dewasa meskipun ia sudah terlibat menjadi tim sukses. Atiek mengatakan bahwa "Sangat disayangkan ketika anak didik saya ini harus meninggalkan kegiatan belajar mengajar di sekolah untuk ikut berkampanye. Belum saatnya bagi anak tersebut menjadi bagian dari tim sukses. Informasi yang diperoleh dari anak didik kami mengenai alasan mengapa ia terlibat sebagai tim sukses yakni karena ia senang mendapatkan kaos dan tambahan uang jajan (hahaha anak-anak memang selalu jujur)."

\subsection{Kendala Peningkatan Partisipasi Politik Masyarakat Pada Penyelenggaraan Pemilu Presiden Tahun 2019}

Pemilihan umum merupakan suatu pesta rakyat bagi warga Negara Indonesia yang diselenggarakan untuk memilih calon pemimpin. Namun, banyak hal yang menyebabkan ketidak gairahan warga Negara untuk ikut terlibat langsung dalam proses pemilihan umum. Di Desa Sidorejo, berdasarkan hasil wawancara dengan Sekretaris Desa mengatakan bahwa "Karena memilih bukan sebuah hak maka bisa digunakan dan bisa juga tidak digunakan karena tidak ada konsekuensi hukum dan moral politik bagi mereka yang tidak memilih." Sebab bagi para warga desa Sidorejo terlibatnya mereka dalam rutinitas ekonomi membuat pilihan politik bukan menjadi prioritas sehingga mempengaruhui cara pandang mereka terhadap politik. Kepala Desa juga mengatakan bahwa "dalam kondisi seperti ini, kita tidak bisa mempersalahkan orang mengapa tidak menggunakan hak politik, karena memilih bukan kewajiban dan ada hal yang lebih penting seperti rutinitas ekonomi yang harus mereka jalani, bukan berpolitik. Tingkat partisipasi politik masyarakat ternyata dipengaruhi oleh adanya praktik politik uang menjelang Pemilu. Terjadinya politik uang dikarenakan saat ini masyarakat mulai dipengaruhi oleh pemikiran yang rasional dalam memandang partisipasi politik. Dari 
hasil penelitian tersebut terbukti masyarakat memiliki pemikiran yang sangat rasional dalam Pemilu. Dorongan uang dalam Pemilu yang selama ini telah terlaksana menjadi sesuatu yang sangat penting bagi masyarakat.

Strategi yang dilakukan oleh aparat desa dalam hal meningkatkan partisipasi politik untuk terlibat dalam penyelenggaraan Pemilu dengan tujuan memancing kesadaran sebagai warga Negara yang tidak hanya memiliki hak saja tetapi juga berkewajiban untuk berpartisipasi politik dengan adanya peran aparat desa membimbing masyarakat, memberikan pengarahan kepada masyarakat, dan menjalin kerjasama dengan masyarakat serta bekerja sama dengan lembaga sosial dalam hal ini KPU untuk memberikan Sosialisasi dan Pendidikan politik dalam meningkatkan partisipasi politik. Namun, ternyata tidak lantas mampu mendorong masyarakat untuk berpartispasi politik secara maksimal. Materi mengenai pengaruh rasionalitas pemilih dalam partisipasi politik yang diberikan oleh KPU mengatakan bahwa makhluk invidiu memiliki tingkat rasionalitas yang sangat tinggi. Sifat dasar dari makhluk rasional adalah kalkulasi untung rugi yang menjadi dasar setiap tindakannya. Hampir semua manusia akan berusaha mendapatkan barang yang dia ingikan dengan ongkos seminimal mungkin. ${ }^{3}$

Hubungannya dengan Pemilu, rasionalitas masyarakat muncul ketika mereka berfikir keuntungan apa yang akan mereka dapatkan ketika mereka menggunakan hak pilihnya. Padahal disisi lain mereka sudah jelas mengeluarkan ongkos dalam Pemilu. Ongkos dalam hal ini sudah pasti tenaga dan waktu, bahkan bisa jadi uang. Misalnya untuk transportasi menuju TPS. Masyarakat mulai berfikir apakah barang yang mereka dapatkan nantinya sebanding dengan ongkos yang mereka keluarkan. Praktik money politic dalam Pemilu dapat dilihat dari pandangan teori pilihan rasional. Salah satu tokoh teori pilihan rasional yang terkenal

${ }^{3}$ Mujani, Saiful, dkk. (2012). Kuasa Rakyat. Jakarta: Mizan Publika, Hlm. 306 
adalah James S. Coleman. Coleman menganggap bahwa setiap tindakan yang dilakukan oleh seseorang dipengaruhi oleh tujuan dan nilai yang diinginkan oleh mereka. Selanjutnya menurut Coleman dalam teori pilihan rasional ada dua unsur yang terlibat yakni aktor dan sumber daya. Uang menjadi salah satu motivasi bagi seseroang untuk berpartisiapsi dalam politik.

Pada akhirnya teori pilihan rasional Coleman telah mampu menjelaskan adanya keterkaitan antara aktor dan sumber daya dalam hubungannya dengan politik uang dalam Pemilu. Rasionalitas masyarakat ternyata telah memberikan pengaruh pada mereka untuk menentukan apakah mereka ikut memilih atau tidak. Uang dianggap sebagai sebuah keuntungan yang seharusnya mereka dapatkan ketika mereka sudah berkorban waktu dan tenaga untuk menggunakan hak pilihnya ke TPS. Pendapat lainpun di ungkapkan oleh Antony Downs memberikan penjelasan mengenai adanya keterkaitan antara pemilihan umum dengan teori pilihan rasional. Kehidupan politik saat ini tidak hanya murni dipengaruhi oleh kepentingan politik. Namun sudah lebih banyak dipengaruhi oleh kepentingan ekonomi di dalamnya. Begitu juga dengan Pemilu, banyak muncul pertimbangan-pertimbangan ekonomi yang difikirkan oleh masyarakat sebagai pemilih.

\section{Penutup}

Upaya meningkatkan partisipasi politik masyarakat merupakan bagian yang paling penting dalam sebuah penyelenggaraan Pemilu, sebab tingkat partisipasi politik masyarakat ternyata dipengaruhi oleh adanya praktik politik uang yang kerap terjadi menjelang Pemilu. Terjadinya politik uang dikarenakan saat ini masyarakat mulai dipengaruhi oleh pemikiran yang rasional dalam memandang partisipasi politik. Dari hasil penelitian, terbukti masyarakat memiliki pemikiran yang sangat rasional dalam Pemilu. Dorongan uang dalam Pemilu menjadi sesuatu yang sangat penting bagi masyarakat. Pada intinya masyarakat akan menentukan untuk berpartisipasi ketika partisipasi tersebut 
memberikan keuntungan secara nyata kepada dirinya. Strategi yang dilakukan oleh aparat desa dalam hal meningkatkan partisipasi politik untuk terlibat dalam penyelenggaraan Pemilu dengan tujuan memancing kesadaran sebagai warga Negara yang tidak hanya memiliki hak saja tetapi juga berkewajiban untuk berpartisipasi politik dengan adanya peran aparat desa membimbing masyarakat, memberikan pengarahan kepada masyarakat, dan menjalin kerjasama dengan masyarakat serta bekerja sama dengan lembaga sosial dalam hal ini KPU untuk memberikan Sosialisasi dan Pendidikan politik dalam meningkatkan partisipasi politik. Meskipun, lembaga sosial juga tidak selalu mampu mendorong masyarakat dalam meningkatkan partisipasi politiknya dikarenakan lembaga sosial banyak memiliki keterbatasan dalam memberikan sosialisasi dan pendidikan politik kepada masyarakat. 


\section{Daftar Pustaka}

Buku

Amiruddin, Ibramsyah. (2008). Kedudukan KPU Dalam Struktur Ketatanegaraan Republik Indonesia Pasca Amandemen. Jakarta: Laksbang Mediatama

Budiarjo, Miriam. (1992). Partisipasi dan Partai Politik. Jakarta: PT Gramedia Widia Juliantara, Dadang. (1998). Meretas Jalan Demokrasi. Yogyakarta: Kanisius

Lexi J, Moleong. (2006). Metode Penelitihan Kualitatif. Bandung: PT. Remaja Rosdkarya

Mujani, Saiful, dkk. (2012). Kuasa Rakyat. Jakarta: Mizan Publika

Nawawi, Hadari, dan Mimi, Martini. (1994). Penelitian Terapan. Yogyakarta: Gajah Mada University Press

Nasuka, H. (2007). Partisipasi Rakyat dan Anggota TNI dalam Pemilu. Bandung: Mandar Maju

Said, Mas'ud. (2007). Birokrasi di Negara Birokratis, Malang: UMM Press

Sastroatmojo, Sudijono. (1995). Perilaku Politik. Semarang: IKIP Semarang

Sugihen, Bahren. (1997). Sosiologi Pedesaan Suatu Pengantar, Jakarta: Grafindo Persada

Surbakti, Ramlan. (2003). Memahami Ilmu Politik. Jakarta: PT Gramedia Widiasarana Indonesia

Perundang-undangan:

Undang-Undang Dasar Negara Republik Indonesia Tahun 1945

Undang-Undang No. 6 Tahun 2014 Tentang Desa

Undang-Undang No. 23 Tahun 2014 Tentang Pemerintah Daerah

Undang-Undang No. 7 Tahun 2017 Tentang Pemilihan Umum 